\title{
Phyllosphere Bacterial Population of Woody Species in Subtropical Forest at Shivapuri-Nagarjun National Park, Nepal Himalaya
}

\author{
Ram Kailash P. Yadav*, Sushila Shrestha, Chandra P. Pokhrel, Pramod Kumar Jha \\ Central Department of Botany, Tribhuvan University, Kirtipur, Kathmandu, Nepal \\ *rkp.yadav@cdbtu.edu.np
}

\begin{abstract}
Seasonal variation of phyllospheric bacteria and their leaf traits of four woody species of subtropical environment were studied at Shivapuri Nagarjun National Park. The four species examined were Alnus nepalensis D. Don., Schima wallichii (DC.) Korth., Rhododendron arboreum Smith. and Gaultheria fragrantissima Wall. The first species is deciduous, second is semi-deciduous and other two are evergreen. The leaf samples were collected during summer and winter seasons in 2010. The estimation of bacterial population was done by the serial dilution plating method using Nutrient Agar Glycerol Medium. The leaf traits such as leaf water content, nitrogen content, phosphorous content, sugar content and specific leaf mass were also estimated. The bacterial population of four woody species ranges from 2.87 to $5.48 \mathrm{log}$ CFU per $\mathrm{g}$ f.w. The epiphytic bacterial populations differed among seasons and among species. In subtropical environment bacterial population was found to be limited to leaf phosphorous content.
\end{abstract}

Keywords- Phyllosphere; Epiphytic Bacterial Population; Leaf Traits; Woody Species; Subtropical Forest; Himalaya

\section{INTRODUCTION}

The plant phyllosphere represents the habitat provided by the above ground parts of plants, mainly the leaf surfaces. The global surface area of the phyllosphere has been estimated to be over $4 \times 10^{8}$ sq.km. supporting bacterial populations in the region of $10^{26}$ cells [1]. On a global scale plant phyllosphere supports a large and complex microbial community [2]. Plant phyllosphere is a home to wide variety of microorganisms including bacteria, fungi and yeasts. In most instances, bacteria are

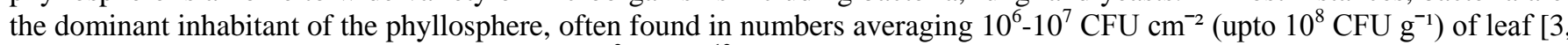
$4]$ and with culturable counts ranging between $10^{2}$ and $10^{12}$ cells per gram of leaf [5-7].

The leaf is unique as a habitat for epiphytic microbes. It is ephemeral lasting only for few weeks in woody perennial species. The average leaf life span of deciduous species is 38 weeks while being higher in evergreen species, i.e. 57 weeks [8]. It is highly dynamic, exposed to pronounce cyclic and non-cyclic variation of environmental conditions [9] and unlike most or less arbitrarily defined - the leaf margin clearly delineates the boundary of the microbial community. A wide range of microorganisms survives and proliferates in the phyllosphere and is characterized by a multitude of topographical features, sources of nutrients and water and a range of microclimatic conditions that are often conducive to the survival or growth of diverse microorganisms.

Epiphytic bacterial communities are subjected to frequent and rapid alteration between highly varying states of environmental factors such as temperature, relative humidity and wind speed, radiation, any one of which may be considered stressful to at least some bacteria [4]. There is great variability in bacterial communities even within the same species in tree canopies of Tropical Atlantic Forest [10]. Recent investigations emphasize the negative effects of air pollutants on the phyllosphere microbial community [11]. A typical feature of epiphytic bacterial population is the high variability in space and time. Population sizes can vary enormously even among adjacent, visually identical leaves of the same individual [9]. The number of bacteria, for example, on different leaves in a given canopy or among square-millimeter sites on a single leaf can vary in size among and within plant species over short periods of time [12] as well as over the growing season [5, 6, 7, 13]. Leaf age also greatly influences the epiphytic bacterial population [5, 14]. Generally, mature leaves are the most highly populated than younger ones and there is variation in population size even on the adaxial and abaxial leaf surfaces of the same leaf [15].

Microbes reach the phyllosphere by atmospheric deposition from plant and soil sources, but may also colonize plants through the roots, and become transported to aerial parts. Epiphytic filamentous fungi, yeasts and bacteria may arrive on the leaf surface through insect, atmosphere, seed or even animal borne sources [2]. Tree buds, seeds of annual plants and debris from previous crops tend to be the most important sources for the colonization of new plants and leaves as they are a major source of bacteria already adapted to the phyllosphere [16].

The phyllosphere bacteria have significant effects in the field of agriculture and environment. These may affect the fitness of natural plant populations and quality and productivity of agricultural crops [2]. Phyllosphere bacteria can promote plant growth and both suppress and stimulate the colonization and infection of tissues by plant pathogens [17, 18]. Interactions in the phyllosphere zone determine the extent to which human pathogens are able to colonize and survive on the plant tissues, an area 
of great importance with the rise in cases of human disease associated with consumption of fresh salad, fruit and vegetable products [2]. Recent investigations have also identified that fruits and vegetables are the source of many disease outbreaks [19]

Microorganisms play an important role in more global process such as nitrogen fixation [20, 21] and nitrification [22]. The methylotrophic bacteria found in the phyllosphere has an important role in the degradation of methanol [23, 24]. Another environmentally important microbial process, for which there is direct evidence, is that bacteria on leaves can degrade organic pollutants from the air (e.g. air borne phenol). It indicates that bacteria on the leaf could potentially contribute to the natural attenuation of organic air pollutants [25]. Therefore, it is realized that understanding of the ecology of epiphytic bacteria is both of scientific and economical importance [17]. However, there has been little study of bacterial communities on the surfaces of plants [26].

In Nepal, soil microflora was studied to examine the influence of precipitation, temperature and altitude on microbes in soils [27]. The bacterial populations on the leaf surface of plants that harbor huge diversity of microorganisms, however, have not been studied. This work is just a beginning, and is aimed at unraveling the pattern of bacterial abundance in the leaves of woody plants in natural forests of the Himalayan ecosystem.

\section{MATERIALS AND METHODS}

\section{A. Study Area, Plant Species and Sampling}

The study was carried out in Shivapuri Nagarjun National Park (SNNP) situated in the middle mountain region of the Central Himalaya, Nepal. The latitude and longitude of the study site is $27^{\circ} 47.583^{\prime} \mathrm{N}$, and $085^{\circ} 22.421^{\prime}$ E respectively; and the elevation is $1740 \mathrm{~m}$ a.s.l. (Fig. 1). The sampling was done on the south facing aspect of the hill. The park is located in a transition zone between subtropical and temperate climate with rainy summer and dry winter; the study site is an upper subtropical region. For the period of 2000 to 2009 , the highest maximum average temperature was $27.85^{\circ} \mathrm{C}$ and the minimum average temperature was $3.26^{\circ} \mathrm{C}$ in the area (Fig. 2). The average annual rainfall was $1969.15 \mathrm{~mm}$ for the same period.

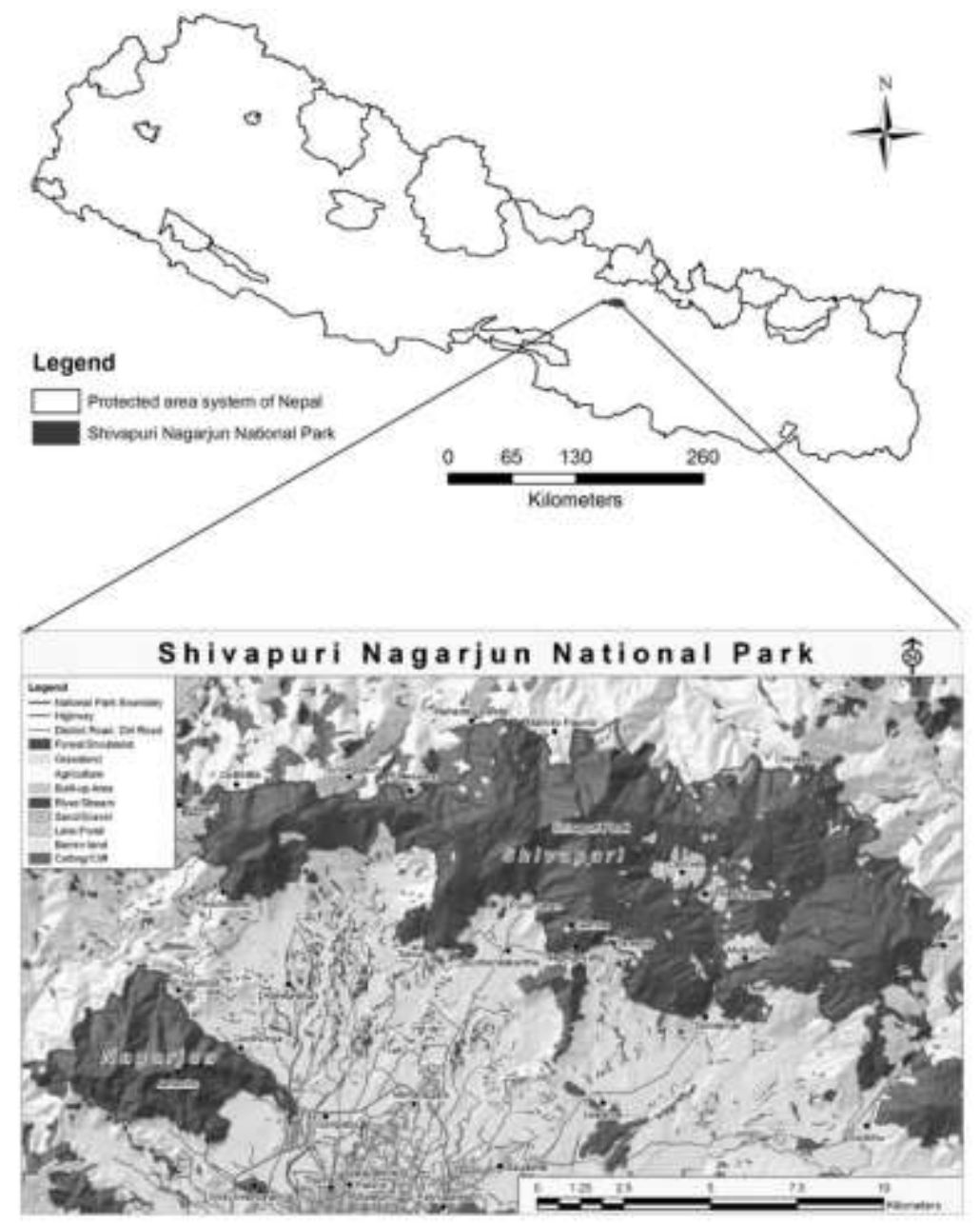

Fig. 1 Map of study area Source: Mountain Environment and Natural Resources' Information System (MENRIS), International Center for Integrated Mountain Development (ICIMOD) and Department of National Park and Wildlife Conservation (DNPWC). 


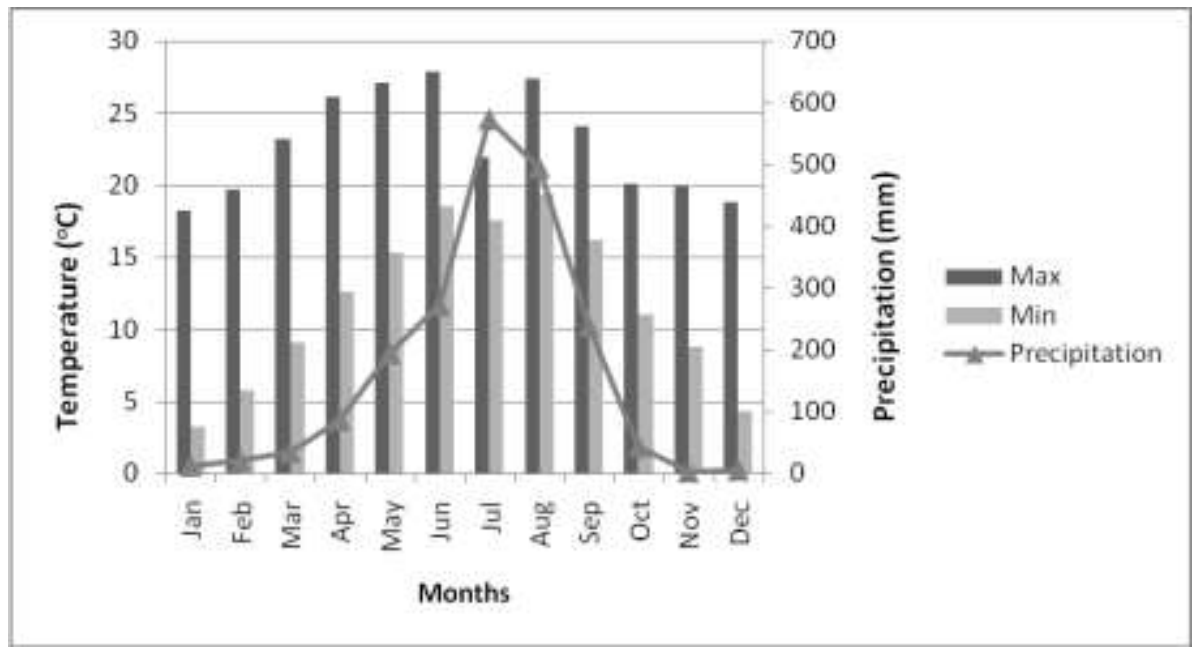

Fig. 2 Seasonal temperature and precipitation pattern of study area Ten years (2000 to 2009) data are averaged for each month (Source: Department of Hydrology and Meteorology, 2010).

Four naturally occurring and coexisting woody plant species were selected as model plants. The plant species are the deciduous Alnus nepalensis D. Don., the semi-deciduous Shima wallichii (DC.) Korth., and the evergreens Rhododendrn arboreum Sm. and Gaultheria fragrantissima Wall. G. fragrantissima is an aromatic plant. All four species constitute the major components of the natural vegetation in the area. Leaf sampling was done twice, in July (summer) and in December (winter), 2010. Sampling always took place in the morning. In all cases, samples consisted of mature leaves, collected at random from three individuals per species. Three samples were taken from each marked individual, thus making nine samples per species. The same scheme was followed for other leaf traits as well.

\section{B. Estimation of Phyllosphere Bacterial Population}

Immediately after sampling, leaves were placed in sterile plastic bags, transported to the laboratory in an icebox, and analyzed within $24 \mathrm{~h}$. The serial dilution plating method onto nutrient agar glycerol (NAG) media [7, 28] was used to estimate total bacterial population of the phyllosphere. Bacterial populations were estimated after incubation at $24^{\circ} \mathrm{C}$ for $2-5$ days. Results are expressed as log CFU per gram fresh weight, where CFU corresponds to colony forming units. The reasons for the $\log$ transformation of data were to meet probability distribution assumptions as described in detail by Hirano et al. (1982)[29] and Yadav et al. (2004) [7].

\section{Leaf Traits}

Leaf traits were measured using standard methods. Leaf water content (LWC) was computed after the following equation: LWC $=$ [(leaf fresh weight - leaf dry weight)/leaf fresh weight] $x 100$ [30]. Total nitrogen content was determined by the Kjeldahl method. Phosphorus was determined colorimetrically by the molybdenum blue method [31]. Soluble sugars were extracted from powdered dry material with $60 \%$ ethanol and were determined colorimetrically according to the phenol-sulfuric acid method [32]. We estimated the specific leaf mass (SLM) as the ratio of leaf dry mass to leaf area [33]. Dry leaf mass was determined by oven drying the leaves at $70^{\circ} \mathrm{C}$ for $72 \mathrm{~h} \mathrm{[34],} \mathrm{and} \mathrm{leaf} \mathrm{area} \mathrm{was} \mathrm{measured} \mathrm{following} \mathrm{Zobel} \mathrm{et} \mathrm{al.} \mathrm{(1987)[35].}$

\section{Statistical Analysis}

Statistically significant differences in bacterial population and different leaf traits between two seasons were determined by student's t-test. The effects of plant species, season, and their interaction on population abundance as well as leaf traits were assessed with analysis of variance (two-way ANOVA). Principle Component Analysis (PCA) was used to separate the four woody species on the basis of their leaf traits and the relationship was sought between the first component scores and total bacterial population. All analyses were performed by using SPSS for Windows (16.0.0, SPSS Inc., USA).

\section{RESULTS}

\section{A. Bacterial Population in the Phyllosphere}

Total bacterial populations in the phyllosphere of the four woody species are given in Fig 3. There is significant seasonal variation in the deciduous $A$. nepalensis with the highest values and the evegreen $R$. arboretum $(p<0.01)$. But this pattern is not consistent in the other two species. As regards the four species, summer values are higher in A. nepalensis and $R$. arboretum, the reverse is true for $S$. wallichii and $G$. fragrantissima. Two-way ANOVA revealed that neither species nor season alone explain the pattern in phyllosphere bacterial population in the species studied in subtropical environment, rather it is better explained combined by both species and season $(p<0.01)$. 

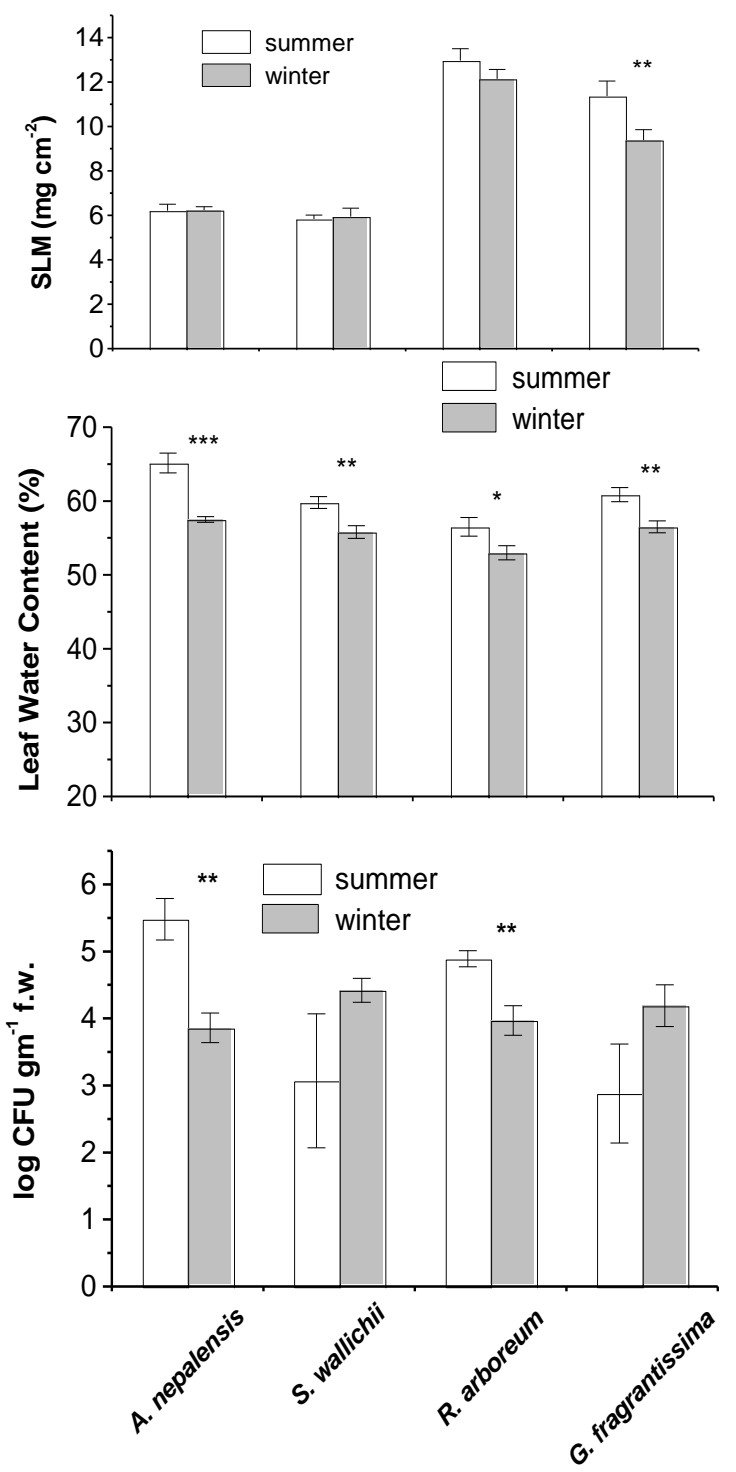

Fig. 3 Bacterial population on the phyllosphere, leaf water content and Specific Leaf Mass (SLM) of summer and winter seasons Vertical columns and bars on top of them represent means and standard errors $(\mathrm{N}=9)$, respectively. Asterisks indicates significant differences between summer and winter seasons at $p<0.05(*) ; p<0.01(* *) ; p<0.001(* * *)$ (Student t-test).

\section{B. Leaf Traits}

Leaf water content varies among species and in seasons (Fig. 3). Although members of different groups do not always differ regarding their content of leaf water, the deciduous A. nepalensis and semi-deciduous S. wallichii on average have higher values than the evergreen species. The results of two-way ANOVA further substantiate the fact that leaf water content in the studied species varies independently among species and in seasons $(p<0.001)$. Specific leaf mass (SLM) corresponding to the ratio of leaf dry mass to leaf area differs significantly among species (Figure 3). The two-way ANOVA showed that SLM differed significantly among plant species and among seasons. Significant difference was not observed in interaction term. This indicates that the SLM is plant species specific and season specific $(p>0.05)$.

The seasonal variation of leaf nitrogen content within species is not found significant in all four species (Fig. 4). However, variation among species is significant, the concentration is higher in the deciduous and semideciduous (A. nepalensis and $S$. wallichi, respectively) than that found in the evergreen species ( $R$. arboretum and $G$. fragrantissima). Concomitant with this, the two-way ANOVA revealed that season was not a significant factor in explaining leaf nitrogen concentration. Rather, the interaction between plant species and season $(p<0.001)$ has effect on the nitrogen concentration. The highest mean leaf phosphorous content was found in the deciduous Alnus nepalensis, both in summer $\left(2.39 \mathrm{mg} \cdot \mathrm{g}^{-1}\right)$ and winter $\left(1.49 \mathrm{mg} \cdot \mathrm{g}^{-1}\right)$, while it was lowest in the evergreens in Rhododendron arboreum $\left(0.83 \mathrm{mg} \cdot \mathrm{g}^{-1}\right)$ in summer and in Gaultheria fragrantissima $\left(1.30 \mathrm{mg} \cdot \mathrm{g}^{-1}\right)$ in winter (Fig. 4). Analysis of variance showed that both seasons and plant species determine the leaf phosphorus concentration in the woody species in the study region $(p<0.01)$. Levels of leaf soluble sugars vary among species but without any discernible life-form related trend; the highest value was recorded in the evergreen shrub G. fragrantissima both in 
summer and winter $\left(134.43 \mathrm{mg} \cdot \mathrm{g}^{-1}\right.$ and $93.36 \mathrm{mg} \cdot \mathrm{g}^{-1}$ respectively). The lowest values are recorded in the deciduous $A$. nepalensis in both seasons (Fig. 4). However, the two-way ANOVA revealed that not only the leaf soluble sugars content differed significantly $(p<0.001)$ among plant species and among different seasons, but also their interaction was significant $(p$ $<0.001)$. This indicates that effect of season on leaf soluble sugars content varied among plant species.

Correlation analysis of the leaf traits of both seasons gave significant results in a number of cases (Table 1). The LWC is correlated with all leaf traits except for soluble sugars. It is significantly correlated with phosphorous content $(\mathrm{r}=0.489, p$ $<0.01)$ and negatively correlated with SLM. The nitrogen and the phosphorous are the most highly correlated ( $\mathrm{r}=0.641, p$ $<0.01)$. The nitrogen and phosphorous are negatively correlated with sugar and SLM.
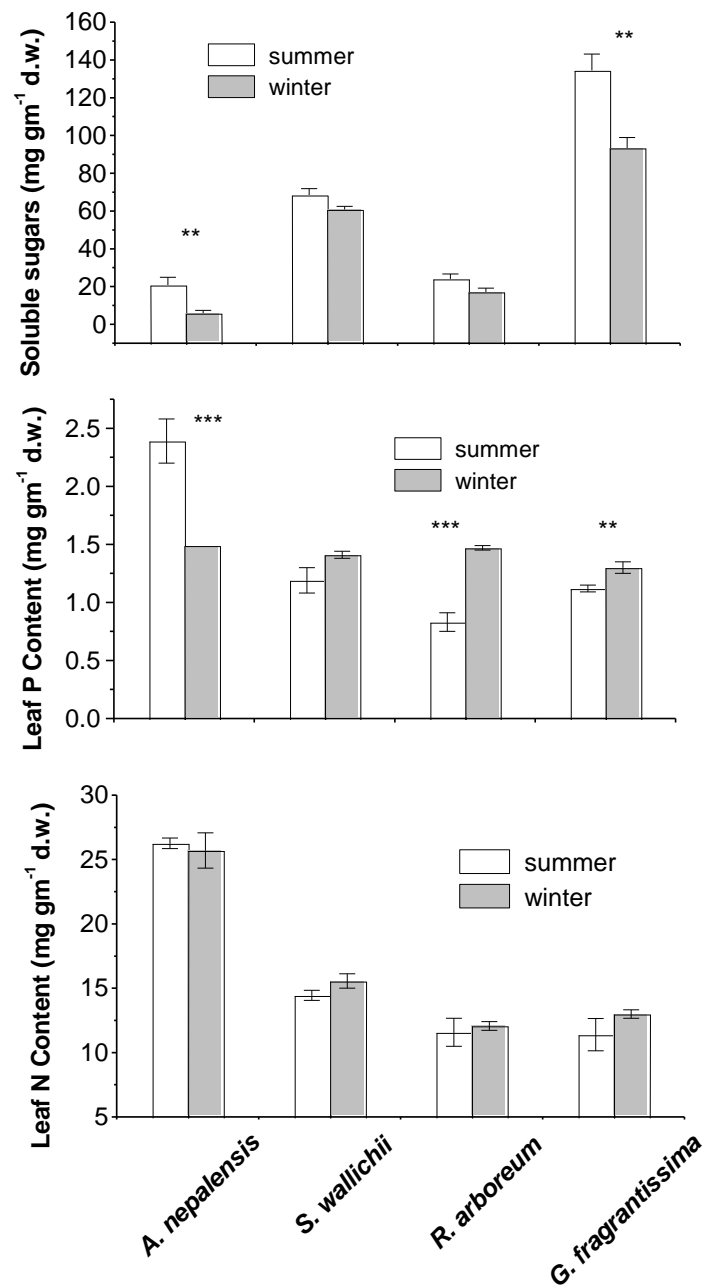

Fig. 4 Leaf nitrogen content, leaf phosphorous content and leaf soluble sugars content of summer and winter seasons Vertical columns and bars on top of them represent means and standard errors $(\mathrm{N}=9)$, respectively. Asterisks indicate significant differences between summer and winter season at $p<0.01(* *) ; p$ $<0.001(* * *)$ (Student t-test).

TABLE 1 MATRIX OF CORRELATION COEFFICIENTS (R) OF SUMMER AND WINTER SEASONS SHOWING RELATIONSHIPS BETWEEN QUANTITATIVE LEAF TRAITS $(\mathrm{N}=72)$

\begin{tabular}{|l|l|l|l|l|}
\hline & LWC & Nitrogen & Phosphorous & Sugar \\
\hline Nitrogen & $0.422^{* *}$ & & & \\
\hline Phosphorous & $0.489 * *$ & $0.641^{* *}$ & & \\
\hline Sugar & $\mathrm{ns}$ & $-0.476^{* *}$ & $-0.338^{* *}$ & \\
\hline SLM & $-0.442^{* *}$ & $-0.637^{* *}$ & $-0.424 * *$ & $\mathrm{~ns}$ \\
\hline
\end{tabular}

Results of PCA are presented in Fig. 5 and Fig. 6. The first two components of the PCA explain 75.64\% of the total variance. Deciduous $A$. nepalensis and semi deciduous species $S$. wallichii are clearly separated from the evergreen sclerophyllous $R$. arboreum and $G$. fragrantissima along the first axis, which accounts for $53.44 \%$ of the total variance. The leaf water content, leaf nitrogen and phosphorus contents on the positive side; and leaf sugar content and SLM on the negative side of the first axis are the traits primarily responsible for this separation. Along the second axis, explaining $22.20 \%$ of the total variance, species is separated after the leaf water content and sugar content against SLM and nitrogen. 


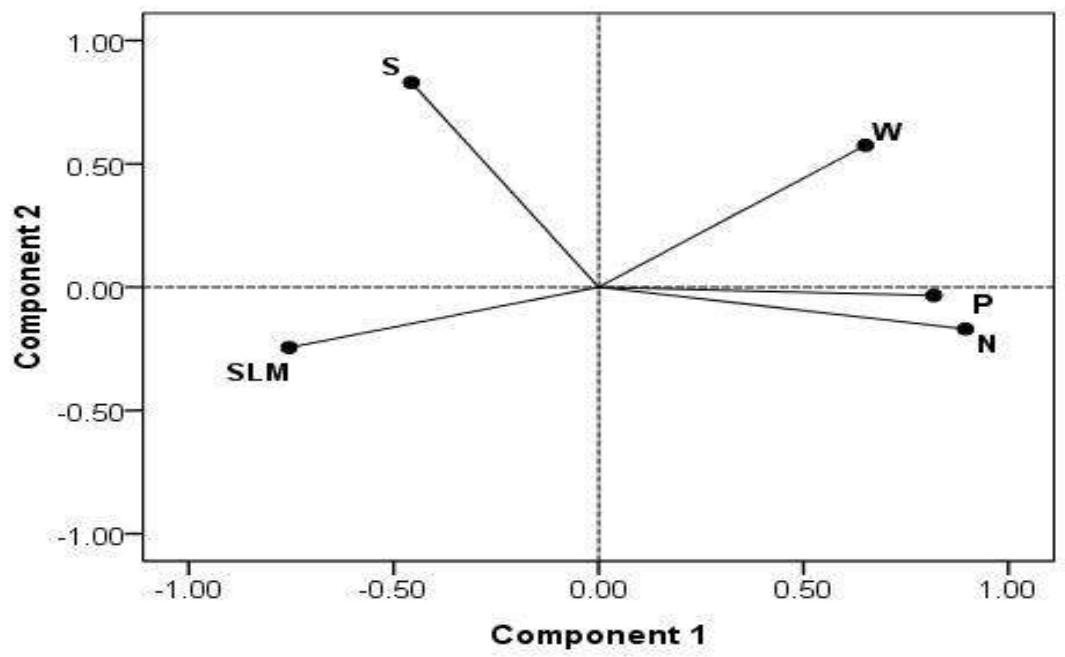

Fig. 5 Component loading of the first two principal components of PCA of leaf traits of the four woody species The first axis accounts for $53.44 \%$ of the total variance and the second for $22.20 \%$. (SLM = specific leaf mass, $\mathrm{S}=$ sugar, $\mathrm{W}=$ water, $\mathrm{P}=$ phosphorus, $\mathrm{n}=$ nitrogen).

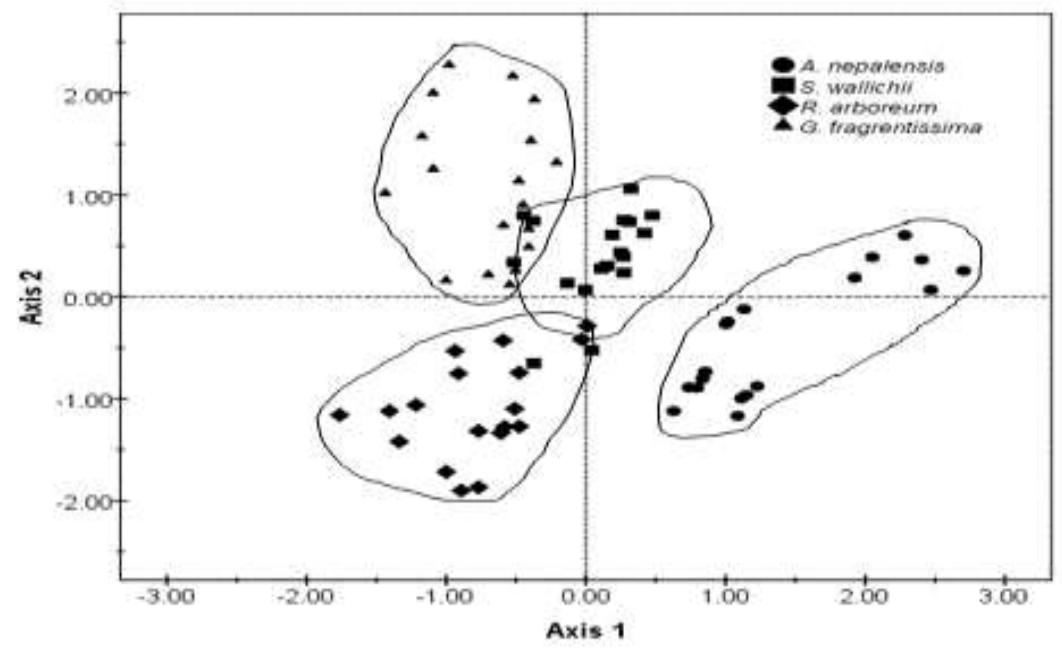

Fig. 6 Projection of the four woody species on the first two principal components on the basis of their leaf traits The first and second axes account for $53.44 \%$ and $22.20 \%$ of the total variance respectively.

\section{Relationships of the Phyllosphere Bacterial Population with Leaf Traits}

The size of the phyllosphere bacterial population is correlated with the number of traits (Table 2). It is positively correlated with phosphorous content and negatively with sugar content. The relationship with other leaf traits is not significant.

TABLE 2 CORRELATION ANALYSES BETWEEN LEAF TRAITS AND THE SIZE OF THE BACTERIAL POPULATION. GIVEN ARE THE CORRELATION COEFFICIENT (r) VALUES ( $\mathrm{N}=72$ )

\begin{tabular}{|l|l|}
\hline Leaf traits & $\mathbf{r}$ \\
\hline LWC \% & $\mathrm{ns}$ \\
\hline Nitrogen & $\mathrm{ns}$ \\
\hline Phosphorous & $0.287^{*}$ \\
\hline Sugar & $-0.348^{* *}$ \\
\hline SLM & $\mathrm{ns}$ \\
\hline
\end{tabular}

ns: not significant, $* p<0.05, * * p<0.01$

Regression analysis was done between the size of bacterial population and the first component scores of the PCA of the species after their leaf traits (Table 3). The relationship was found significant. This means that microbial abundance in the phyllosphere of the species examined is influenced by the pattern of variation in leaf traits. 
TABLE 3 REGRESSION ANALYSIS BETWEEN THE SIZE OF BACTERIAL POPULATION AND THE FIRST COMPONENT SCORES OF THE SPECIES LEAF TRAITS (DERIVED FROM THE ANALYSIS SHOWN IN FIG. 5)

\begin{tabular}{|l|c|c|}
\hline \multicolumn{3}{|c|}{$\begin{array}{l}\text { First component scores of the species leaf traits vs. size of the phyllosphere } \\
\text { bacterial population }\end{array}$} \\
\hline Model & Value & Significance* \\
\hline Constant & 4.094 & $\mathbf{0 . 0 4 1}$ \\
\hline B & 0.388 & $\mathbf{0 . 0 4 1}$ \\
\hline$R$ & $0.242\left(R^{2}=0.058\right)$ & \\
\hline \multicolumn{2}{|l}{} \\
\hline
\end{tabular}

\section{DISCUSSION}

The average values of bacterial population found in the phyllosphere of evergreen Rhododendron arboreum and semideciduous Schima wallichii are comparable with the values reported in the study by Yadav et al. (2004) [7]; deciduous species Alnus nepalensis with that found in the study of Lindow et al. (1978) [28]; and the aromatic species Gaultheria fragrantissima with that in Karamanoli et al. (2000) [36]. They are comparable in size of epiphytic bacterial population but in different conditions. Moreover, aromatic plants always do not differ from the other non-aromatic species that co-exist in the same habitat regarding the bacterial communities that they harbour on their leaves [37].

There is no obvious seasonal pattern of change in the population of phyllosphere bacteria in these species in a subtropical environment. Higher bacterial populations were found in summer and lower in winter in all species, but this pattern is more pronounced in A. nepalensis and $R$. arboreum. The lowest phyllosphere bacterial populations were recorded for most of species in summer in Mediterranean environment in previous report [7]. This may be because the Mediterranean environment is hot and dry in summer whereas the summer in the present study area is considerably wet. Others have observed this pattern for some but not all perennial species [38]. According to average climatic data of past ten years in the study area, the summer season (June-July) is characterized by heavy rainfall and moderate temperature. Such environment is conducive for epiphytic microorganism growth and, therefore, a higher population size is expected in summer. Moreover, the bacterial community diversity (species number) has been reported lowest in mid season corresponding to the warmest driest period in the study area and greatest during high rainfall and low temperature [5].

The seasonal variation of bacterial population found in Alnus nepalensis and Rhododendron arboreum is in agreement with earlier reports which state that seasonal differences do occur in phyllosphere communities in the context of changing environmental conditions [39]. Plant species and season have combined effect on the bacterial populations. Similar results were also found by other researchers [5, 39], who state that season had great influence on the epiphytic bacterial populations. Kinkel et al. (2000) [40] and Knief et al. (2010) [41] together suggested that bacterial population size differ significantly among plant species. According to them, the size of bacterial populations did not show clear pattern regarding the deciduous and evergreen species, although relatively lower values were found in the evergreens. Leaf age and leaf surfaces also influence the abundance of phyllosphere bacterial populations [15]. Concomitant with this, it was reported that bacterial abundance on the phyllosphere were negatively correlated with the concentration of phenolic substances, thickness of total leaf, mesophyll thickness and thickness of leaf cuticle [42].

Although not clearly visible, the deciduous species studied here showed higher leaf water content than the evergreens, particularly in summer months. It may be because deciduous species in summer season perform higher photosynthesis, the photosynthate goes for the growth and development of foliages and hence these species require higher water content than evergreens [34]. This pattern is also reported by Yadav et al. (2005) [42]. The evergreen species (Rhododendron arboreum and Gaultheria fragrantissima) exhibit higher SLM which is approximately twice as higher as in the deciduous species (Alnus nepalensis). The result is comparable to previous reports [7, 43, 44]. However, the values obtained in this study are slightly lower than the values obtained by Gratani and Bombelli [45] in evergreen sclerophyllous species as greater proportion of carbon is invested in their structure to cope with stress conditions thereby increasing the SLM.

Deciduous Alnus nepalensis generally maintains higher leaf nitrogen and phosphorus contents than evergreen Rhododendron arboretum. Besides being deciduous species, the roots of A. nepalensis are nodulated with Frankia as an endophyte which is $\mathrm{N}_{2}$-fixing microorganism [8]. Species at the nutrient conserving end of the spectrum typically have long leaf lifespan, high leaf mass per unit area, low leaf nutrient concentration, and low photosynthetic capacity [46]. However, the deciduous species with short leaf lifespan need to maximize photosynthetic rates and thus require large investment of nitrogen and other substrates. The internal nitrogen cycling efficiency in deciduous species is also significantly greater than in evergreen species [8]. Similar nutrient concentrations are reported in Nothofagus species [43] and component species of the Mediterranean ecosystem [42]. The seasonality in the leaf soluble sugar was only observed in the A. nepalensis and G. fragrantissima for which leaf soluble sugar was higher in summer season. Study by Meletiou - Christou et al. (1998) [47] reported that soluble sugars increased in all parts of plant during the summer while starch and total lipid decreased. Summer season is the period of full sun light for longer time period, so plants take advantage of it and grow faster. 
Results of correlation analysis revealed that two out of five leaf traits are related with the bacterial population in the phyllosphere. Leaf phosphorus content is positively correlated while soluble sugar content is negatively correlated. Mercier and Lindow (200) [48] argue that the initial sugar abundance on uncolonized leaves is the primary determinant of the total bacterial population size that leaves can support after inoculation. Other tested traits are not correlated and leaf traits have been found correlated with each other. Studies from Meditteranean environment have shown that population size of epiphytic bacteria is strongly regulated by higher leaf water content, followed by phosphorous content and nitrogen content [36, 42]. But according to findings of the present study, the population size of epiphytic bacteria is primarily phosphorous limited in the upper subtropical environment of the central Himalayan region. Although not specific to any particular environment, this result is in agreement with Schonherr and Baur (1996) [49], according to whom ATP or other polar P - containing compounds are unlikely to penetrate cuticles in significant amounts while monosaccharides do not diffuse across intact cuticles in rates required to sustain growth of epiphytic microorganisms. Hence, the availability of phosphorous may well be growth limiting for epiphytic microbes.

Correlation analysis gives some insight as to which of the leaf traits examined are related with the abundance of microbes on leaf surfaces. However, in cases of complex systems, there are a number of variable interdependencies. To have a comprehensible description of the leaf-microbe system's behavior, we used regression analysis between first component scores of PCA that included leaf N, P and water as main contributors, and total bacterial population in the phyllosphere. As a result, we found that the relationship is significant, further verifying that leaf phosphorus describes the pattern of bacterial abundance in the phyllosphere of major plant species.

\section{CONCLUSIONS}

Although limited in scope, this initial study reveals a pattern of bacterial population in the phyllosphere of woody species. The deciduous species are usually heavily colonized than the evergreens. The effect of season appeared plant species specific. Of the leaf traits examined, leaf phosphorus content appeared to affect the abundance of bacterial population in the phyllosphere of studied species in the subtropical environment. To understand the plant-microbe system, it is essential to expand the study to wide range of species and also to the other environments. As we begin to survey the bacterial population abundance through systematic surveys of different plants, there will be exciting opportunities for studies of the metabolic capabilities and the ecological functions of phyllosphere microorganisms in terrestrial ecosystems.

\section{ACKNOWLEDGEMENTS}

The study was supported by Nepal Academy of Science and Technology (NAST). Department of National Parks and Wildlife Conservation (DNPWC), Government of Nepal and Shivapuri Nagarjun National Park are acknowledged for granting permission to carry out the research. Sample analyses were done at the laboratory of Central Department of Botany, Tribhuvan University, Kirtipur, Kathmandu, Nepal.

\section{REFERENCES}

[1] C. E. Morris and L. L. Kinkel. "Fifty years of phyllosphere microbiology: significant contributions to research in related fields" In: S. E. Lindow, E. I. Hecht-Poinar and V. J. Elliott, editors. Phyllosphere Microbiology. APS Press, Minnesota, pp. 365-375, 2002.

[2] J.M. Whipps, P. Hand, D. Pink and G. D. Bending. "Phyllosphere microbiology with special reference to diversity and plant genotype", J. Appl. Microbiol. vol. 105, pp. 1744-1755, 2008.

[3] J. H. Andrews and R. F. Harris. "The ecology and biogeography of microorganisms on plant surface", Annu. Rev. Phytopathol. vol. 38, pp. $145-180,2000$.

[4] S. S. Hirano and C. D. Upper. "Bacteria in their leaf ecosystem with emphasis on Psudomonas syringae - a pathogen, ice nucleus, and epiphyte", Microbiol. Mol. Biol. Rev. vol. 64, pp. 624-653, 2000.

[5] I. P. Thompson, M. J. Bailey, J. S. Fenlon, T. R. Fermor, A. K. Lilley, J. M. Lynch, P. J. McCormack and M. P. McQuilken. "Quantitative and qualitative seasonal changes on the microbial community from the phyllosphere of sugar beet (Beta vulgaris)", Plant Soil, vol. 150, pp. 177-191, 1993.

[6] J. Inacio, P. Pereira, M. de Carvalho, A. Fonseca, M. T. Amaral- Collaco and I. Spencer- Martins. "Estimation and diversity of phyllosplane mycobiota on selected plants in a Mediterranean-type ecosystem in Poutugal”, Microb. Ecol. vol. 44, pp. 344-353, 2002.

[7] R. K. P. Yadav, J. M. Hally, K. Karamonoli, H. I. Constantinidou and D. Vokou. "Bacteria populations on the leaves of Mediterranean plants: quantitative features and testing of distribution models", Env. Exp. Bot. vol. 52, pp. 63-77, 2004.

[8] J. S. Singh and S. P. Singh. "Forest of Himalaya: Structure, Functioning and Impact of Man", Gyanodaya Prakashan, Nainital, India. 1992.

[9] J. H. Andrews. "Phyllosphere ecology: past, present and future", In: C. E. Morris, P. C. Nicot and C. Nguyen, editors. Aerial Plant Surface Microbiology. Plenum press, New York, pp. 285-294, 1996.

[10] M. R. Lambias, D. E. Crowley, J. C. Cury, R. C. Büll and R. R. Rodrigues. "Bacterial diversity in tree canopies of the Atlantic forest", Science, vol. 312, pp. 1917, 2006.

[11] S. R. Joshi. "Infuence of roadside pollution on the phyllosphere microbial community of Alnus nepalensis (Betulaceae)", Revista de Biología Tropical, vol. 56, pp. 1521-1529, 2008.

[12] S. S. Hirano and C. D. Upper. "Diel variation in population size and ice nucleation activity of Pseudomonas syringae on snap bean leaflets", Adv. Appl. Microbiol. vol. 55, pp. 623-630, 1989. 
[13] D. E. Legard, M. P. McQuilken, J. M. Whipps, J. S. Fenlon, I. P. Fermor, I. P. Thompson, M. J. Bailey and J. M. Lynch. "Studies of seasonal changes in the microbial populations on the phyllosphere of spring wheat modified microorganism", Agric. Ecosyst. Env. vol. 50, pp. 87-101, 1994.

[14] G. L. Ercolani. "Distribution of epiphytic bacteria on olive leaves and the influence of leaf age and sampling time", Microb. Ecol. vol. 21, pp. 35- 48, 1991.

[15] R. K. P. Yadav, K. Karamanoli and D. Vokou. "Bacterial population on the phyllosphere of Mediterranean plants: influence of leaf age and leaf surface", Front. Agric. China, vol. 5(1), pp. 60-63, 2011.

[16] C. R. Manceau and M. N. Kasempour. "Endophytic versus epiphytic colonization of plants: what comes first?" In: S. E. Lindow, E. I. Hecht-Poinar and V. J. Elliott, editors. Phyllosphere Microbiology. APS press, St. Poul, USA, pp. 115-123, 2002.

[17] S. E. Lindow and M. T. Brandl. "Microbiology of the phyllosphere", Appl. Environ. Microbiol. vol. 9, pp. 1875-1883, 2003.

[18] F. Rasche, E. Marco- Noalles, H. Velvis, L. S. Van Overbeek, M. M. Lopez, J.D. Van Elsas and A. Sessitch. "Structural characteristics and plant beneficial effects of bacterial colonizing the shoots of field grown conventional and genetically modified T4- lysosome producing potatoes", Plant Soil, vol. 289, pp. 123-140, 2006.

[19] C. N. Berger, S. V. Sodha, R. K. Shaw, P. M. Griffin, D. Pink, P. Hand and G. Frankel. "Fresh fruit and vegetables as vehicles for the transmission of human pathogens", Environ. Microbiol. vol. 12(9), pp. 2385-2397, 2010.

[20] E. Freiberg. "Microclimatic parameters influencing nitrogen fixation in the phyllosphere in Costa Rican premontane rain forest," Oecologia, vol. 117, pp. 9-18, 1998.

[21] M. Furnkranz, W. Wanek, A. Richter, G. Abell, F. Rasche and A. Sessitsch. "Nitrogen fixation by phyllosphere bacteria associated with higher plants and their colonizing epiphytes of tropical lowland rainforest of Costa Rica", The IMSE Jour. vol. 2, pp. 561-570, 2008.

[22] H. Papen, A. Gessler, E. Zumbusch and H. Rennenberg. "Chemolithoautotrophic nitrifiers in the phyllosphere of a spruce ecosystem receiving high atmospheric nitrogen input", Curr. Microbiol. vol. 44, pp. 56-60, 2002.

[23] W. A. Corpe and S. Rheem. "Ecology of the methylotrophic bacteria on leaving leaf surfaces", FEMS Microbiol. Ecol. vol. 62, pp. 243$250,1989$.

[24] B. Van Aken, C. M. Peres, S. L. Doty, J. M. Yoon and J. L. Schnoor. "Methylobacterium populi sp nov., a novel aerobic pinkpigmented facultatively methylotrophic, methane-utilizing bacterium isolated from poplar trees (Populus deltoides x nigra DN34)", Int. J. Syst. Evol. Microbiol. vol. 54, pp. 1191-1196, 2004.

[25] A. Sandhu, L. J. Halverson and G. A. Beattie. "Bacterial degradation of air borne phenol in the phyllosphere", Env. Microbiol. vol. 9, iss. 2, pp. 383-392, 2007.

[26] M. Kim, D. Singh, A. Lie-Hoe, R. Go, A. R. Rahim, A. N. Ainnuddin, J. Chun and M. J. Adams. "Distinctive phyllosphere bacterial communities in tropical trees", Microb. Ecol. vol. 63, pp. 674-681, 2012.

[27] G. Franz. "The influence of altitude, precipitation and temperature in the investigated region on humus (soils) content and microbial activity in soil samples from Nepal", Pedobiologia, vol. 16, iss. 2, pp. 136-180, 1976.

[28] S. E. Lindow, D. C. Arny and C. D. Upper. "Distribution of ice nucleation- active bacteria on plants in nature" Appl. Environ. Microbiol. vol. 36, pp. 831-838, 1978.

[29] S. S. Hirano, E. V. Nordheim, D. C. Arny and C. D. Upper. "Lognormal distribution of epiphytic bacterial populations on leaf surfaces", Appl. Environ. Microbiol. vol. 44, pp. 695-700, 1982.

[30] L. Gratani and E. Ghia. "Changes in morphology and physiological traits during leaf expansion of Arbutus unedo", Environ. Exp. Bot. vol. 48, pp. 51-60, 2002.

[31] S. E. Allen, editor. "Chemical analysis of ecological materials" Blackwell Science, Oxford. 1989.

[32] M. Dubois, K. A. Gilles, J. K. Hamilton, P. A. Rebers and F. Smith. "Colorimetric methods for determination of sugars and related substances", Anal. Chem. vol. 28, pp. 350-356, 1956.

[33] P. B. Reich, M. B. Walters and D. S. Ellsworth. "Leaf life-span in relation to leaf plant and stand characteristics among diverse ecosystems" Ecol. Monog. vol. 62, pp. 365-392, 1992.

[34] F. Bussotti, D. Bettini, P. Grossoni, S. Mansuinos, R. Nibbi, C. Soda and C. Tani. "Structural and functional traits of Quercus ilex in response to water availability", Environ. Exp. Bot. vol. 47, pp. 11-23, 2002.

[35] D. B. Zobel, P. K. Jha, M. J. Behan and U. K. R. Yadav. "A Practical Manual for Ecology" Ratna Pustak Distribution, Kathmandu, Nepal. 1987.

[36] K. Karamanoli, D. Vokou, U. Menkissoglu and H. I. Constantinidou. "Bacterial colonization of phyllosphere of Mediterranean aromatic plants", J. Chem. Ecol. vol. 26, pp. 2035-2048, 2000.

[37] R. K. P. Yadav, E. M. Papatheodorou, K. Karamonoli, H. I. Constantinidou and D. Vokou. "Abundance and diversity of the phyllosphere bacterial communities of Mediterranean perennial plants that differ in leaf chemistry", Chemoecology, vol. 18, pp. 217226, 2008.

[38] J. Daniel and B. Boher. "Ecology of cassava bacterial blight epiphytic survival of Xanthomonas manihotis on aerial parts of the cassava plant”, In: Station de Pathologie Végétale et Phytobactériologie. Proc. Int. Conf. Plant Pathol. Bact., fourth ed. Institute of National Research on Agriculture, Beaucouzé, pp. 763-771, 1978.

[39] C. R. Jackson and W. C. Denney. "Annual and seasonal variation in the phyllosphere bacterial community associated with leaves of the southern Magnolia (Magnolia grandiflora)”, Microb. Ecol. vol. 61, pp. 113-122, 2011.

[40] L. L. Kinkel, M. Wilson and S. E. Lindow. "Plant species and plant incubation conditions influence variability in epiphytic bacterial population size", Microb. Ecol. vol. 39, pp. 1-11, 2000.

[41] C. Knief, A. Ramette, L. Frances and J. A. Alonso- Blancoc Vorholt. "Site and plant species are important determinants of the mythylobacterium community composition in the plant phyllosphere", The ISME Jour. vol. 4, pp. 719-728, 2010.

[42] R. K. P. Yadav, K. Karamanoli and D. Vokou. "Bacterial colonization of the phyllosphere of Mediterranean perennial species as influenced by leaf structural and chemical features", Microb. Ecol. vol. 50, pp. 185-196, 2005.

[43] F. Hevia, M. Loreto, O. Minoletti, K. L. M. Decker and R. E. J. Boerner. "Foliar nitrogen and phosphorous dynamics of three Chilean Nothofagus (fagaceae) species in relation to leaf life span", Am. J. Bot. vol. 86, pp. 447-455, 1999.

[44] Y. Uprety. "Water relations of Alnus nepalensis D.Don and Cotoneaster bacillaris Wall. Ex. Lindl. in Kirtipur, Kathmandu, Nepal", M.Sc Dissertation. Central Department of Botany, Tribhuvan University, Kirtipur, Kathmandu, Nepal, 2002. 
[45] L. Gratani and A. Bombelli. "Differences in leaf traits among Mediterranean broad -leaved evergreen shrubs", Ann. Bot. Fennici. vol. 38, pp. 15-24, 2001.

[46] P. B. Reich, M. B. Walters and D. S. Ellsworth. "From tropics to tundra: global convergence in plant functioning", Proc. Nat. Acad. Sci. USA, vol. 94, pp. 13730-13734, 1997.

[47] M. S. Meletiou- Christou, G. P. Banilas and S. Diamantoglou. "Seasonal trends in energy contents of storage substances of the Mediterranean species Dittrichia viscosa and Thymelaea tartonraira", Env. Exp. Bot. vol. 39, pp. 21-32, 1998.

[48] J. Mercier and S. E. Lindow. "Role of leaf surface sugars in colonization of plants by bacterial epiphytes", Appl. Env. Microbiol. vol. 66, pp. 369-374, 2000.

[49] J Schonherr and P Baur. "Cuticle permeability studies: a model for estimating leaching of plant metabolites to leaf surfaces", In: C. E. Morris, P. C. Nicot and C. Nguyen. editors. Aerial Plant Surface Microbiology. Plenum Press, New York, pp. 1-23, 1996. 